\title{
Cloning and characterization of polyketide synthase genes for jadomycin B biosynthesis in Streptomyces venezuelae ISP5230
}

\author{
Lei Han, Keqian Yang, Eswar Ramalingam, Roy H. Mosher \\ and Leo $C$. Vining
}

Author for correspondence: Leo C. Vining. Tel: +1 9024942040 . Fax : +19024943736.

Department of Biology, Dalhousie University, Halifax, Nova Scotia, Canada B3H 4J1

\begin{abstract}
Hybridizing fragments in the genomic DNA of Streptomyces venezuelae ISP5230, which produces the jadomycin group of angucycline antibiotics, were detected by probing with actI DNA from Streptomyces coelicolor A3(2). The hybridizing regions were isolated from a $16.5 \mathrm{~kb}$ insert of $S$. venezuelae DNA recovered from a genomic library cloned in a $\lambda$ replacement vector. Subcloning and sequencing of a $4.8 \mathrm{~kb}$ segment of the insert, containing regions hybridizing to actIII as well as actl, identified five open reading frames (ORFs). The deduced polypeptide products of the ORFs closely resemble in sequence the components of streptomycete type-II polyketide synthases (PKSs): the ORF1 product corresponds to the ketoacyl synthase, and the ORF2 product to a polypeptide closely related to the ketoacyl synthase and involved in determining chain length; the ORF3 product matches the acyl carrier protein; ORF4 encodes a bifunctional cyclase/dehydrase; and ORF5 encodes a ketoreductase. Integration into the chromosomal DNA of a plasmid containing a segment of the ORF2-ORF4 region severely depressed jadomycin B biosynthesis; since the integrant showed no change in growth or spore pigmentation, the cloned PKS genes are presumed to encode enzymes in the pathway for jadomycin biosynthesis.
\end{abstract}

Keywords: Streptomyces venezuelae, jadomycins, polyketide synthase gene cluster, gene disruption

\section{INTRODUCTION}

Compounds derived biosynthetically via polyketide intermediates represent one of the largest families of secondary metabolites, and include numerous antibiotics and pigments produced by streptomycetes (for references, see Hopwood \& Sherman, 1990; O'Hagan, 1992). The polyketide synthases (PKSs) that assemble the structural skeletons of polyketides are organized either as large multifunctional enzymes (type-I PKSs) in which the biosynthetic activities are present as domains, or as multienzyme complexes in which the activities are distributed on individual proteins (type-II PKSs). Sequence analysis of cloned PKS genes has shown strong evolutionary

Abbreviation: PKS, polyketide synthase.

The GenBank accession number for the nucleotide sequence reported in this paper is L 33245 . relationships among systems for the biosynthesis of polyketide-derived metabolites in micro-organisms, and between these systems and the fatty acid synthases (Hopwood \& Khosla, 1992). Within the type-II PKSs, the amino acid sequences deduced for proteins of equivalent function are strikingly similar (McDaniel et al., 1993; Shen \& Hutchinson, 1993), and in streptomycetes the nucleotide sequences of the genes themselves have sufficient identity to hybridize under relatively stringent conditions.

Malpartida et al. (1987a, b) demonstrated that digests of genomic DNA from 14 of 18 streptomycetes known to produce polyketide-derived metabolites contained fragments hybridizing with DNA sequences from actI or actIII, the genes encoding ketoacyl synthase and ketoreductase activities, respectively, in the PKS associated with actinorhodin biosynthesis in Streptomyces coelicolor $\mathrm{A} 3(2)$. In several species, the hybridizing fragments have been confirmed as PKS genes: thus the genomic frag- 
<smiles>CC[C@H](C)[C@]1(C)C(=O)O[C@H]2c3cc(C)cc(O)c3C3=C(C(=O)c4c(O[C@H]5C[C@H](O)[C@@H](O)[C@H](C)O5)cccc4C3=O)N21</smiles>

Fig. 1. Jadomycin B.

ments in Streptomyces violaceoruber were shown to contain genes encoding the PKS for granaticin (Sherman et al., 1989), and those in Streptomyces balstedii were identified with a PKS engaged in spore pigment biosynthesis (Blanco et al., 1992).

In the survey by Malpartida et al. (1987a, b), three of seven streptomycetes not then known to produce polyketidederived metabolites, unexpectedly gave genomic DNA fragments that hybridized with the act probes. One of these, Streptomyces parvulus was later found to produce the polyketide-derived antibiotic nonactin (cited by Malpartida et al., 1987b), and Streptomyces venezuelae ISP5230 was subsequently reported to produce jado- mycins (Ayer et al., 1991), a group of pigmented compounds believed from the pattern of isotopic labelling with $\left[{ }^{13} \mathrm{C}\right]$ acetate to be of polyketide origin (S. Ayer, personal communication).

Jadomycin B, the main component of the mixture produced during growth in an isoleucine-containing medium, is glycosylated and has an isoleucine moiety fused into the cyclic structure (Fig. 1). This and related products are formed when $S$. venequelae ISP5230 is grown under stress conditions, and expression of the biosynthesis genes appears to be activated by heat shock (Doull et al., 1994). Although strain ISP5230 differs from $S$. venezuelae UC2374, the strain reported by Malpartida et al. $(1987 \mathrm{a}, \mathrm{b})$ to hybridize with actI and actIII, both strains produce chloramphenicol, and we have verified that both hybridize similarly to the actI probe. We report here the cloning and sequence analysis of the hybridizing DNA in $S$. venezuelae ISP5230. A selective, severe decrease in jadomycin B production when a plasmid containing part of the cloned sequence integrated into the chromosome indicates that the cloned PKS genes are associated with jadomycin biosynthesis, and are not involved in the formation of spore pigments.

\section{METHODS}

Bacteria, plasmids, phages and culture media. The bacterial strains, plasmids and phages used are listed in Table 1. All cultures in liquid media were grown on a rotary shaker at

Table 1. Bacterial strains, plasmids and phages used

\begin{tabular}{|c|c|c|}
\hline Strain & Genotype/phenotype & Source/reference \\
\hline \multicolumn{3}{|c|}{ Streptomyces venezuelae } \\
\hline ISP5230 & Wild type & Doull et al. (1985) \\
\hline $\mathrm{UC} 2374,13 \mathrm{~s}$ & Wild type, $13 \mathrm{~s}$ is a natural variant & Ahmed \& Vining (1983) \\
\hline VS651, VS652 & ISP5230 with integrated pJV63 & This study \\
\hline \multicolumn{3}{|l|}{ Escherichia coli } \\
\hline TG1 & $\begin{array}{l}\text { supE bsd } \Delta 5 \text { thi } \Delta(\text { lac-pro } A B) \mathrm{F}^{\prime}(t r a D 36 \\
\left.\text { pro } A B^{+} \text {lacI lac } Z \Delta \mathrm{M} 5\right)\end{array}$ & Carter et al. (1985) \\
\hline LE392 & $\Delta\left(\right.$ lacIZY 6 galK2 galT22 metB1 $\operatorname{trpR} 55 \lambda^{-}$ & Sambrook et al. (1989) \\
\hline ET12567 & $d a m^{-} d c m^{-} b s d M^{-}$ & MacNeil et al. (1992) \\
\hline \multicolumn{3}{|l|}{ Plasmid } \\
\hline pHJL400 & $t s r, a m p$, lac $Z^{\prime}$ (bifunctional) & $\begin{array}{l}\text { Larson \& Hershberger } \\
\text { (1986) }\end{array}$ \\
\hline pIJ2345 & pBR329 with a $2.2 \mathrm{~kb}$ act I insert & $\begin{array}{l}\text { D. A. Hopwood (John } \\
\text { Innes Institute, } \\
\text { Norwich) }\end{array}$ \\
\hline plJ2346 & pBR329 with a $1.1 \mathrm{~kb}$ actIII insert & D. A. Hopwood \\
\hline pJV62 & $\mathrm{pHJL} 400$ with a $0.6 \mathrm{~kb}$ jad insert & This study \\
\hline pJV63 & pHJL 400 with a $2.6 \mathrm{~kb}$ jad insert & This study \\
\hline pBluescript II & $a m p$, lac $Z^{\prime}$ & Stratagene \\
\hline \multicolumn{3}{|l|}{ Phage } \\
\hline VCSM13 & $\mathrm{Km}^{\mathrm{R}}$ derivative of $\mathrm{M} 13 \mathrm{~K} 07$ & Strategene \\
\hline$\lambda \mathrm{GEM}-11$ & $\lambda$ replacement vector & Promega \\
\hline LH7 & $\begin{array}{l}\lambda \mathrm{GEM}-11 \text { with a } 16.5 \mathrm{~kb} \text { insert from } S \text {. } \\
\text { venequelae ISP5230 }\end{array}$ & This study \\
\hline
\end{tabular}


240 r.p.m. Escherichia coli was incubated at $37^{\circ} \mathrm{C}$ in LuriaBertani medium (Sambrook et al., 1989), supplemented for plasmid selection with ampicillin $\left(100 \mu \mathrm{g} \mathrm{ml}^{-1}\right)$; strain TG1 was the host strain for all DNA manipulations, whereas strain ET12567 was used to generate unmethylated plasmid DNA suitable for transforming $S$. venezuelae ISP5230. Cultures of $S$. venezuelae were normally grown in MYM medium (Doull et al., $1985)$ at $27^{\circ} \mathrm{C}$ for $24-48 \mathrm{~h}$. Thiostrepton $\left(20 \mu \mathrm{g} \mathrm{ml}^{-1}\right)$ was added for selection when required. Cultures producing mycelium from which genomic DNA was extracted were grown in MYM medium supplemented with $5 \mathrm{mM} \mathrm{MgCl}_{2}$. To prepare a vegetative inoculum for jadomycin $\mathrm{B}$ production, $S$. venezuelae was grown in MYM medium as usual for $24 \mathrm{~h}$. Mycelium collected from the culture by centrifugation was incubated in a galactose-isoleucine medium (Doull et al., 1994) for $6 \mathrm{~h}$ at $27^{\circ} \mathrm{C}$. For jadomycin B production, the culture was supplemented to $6 \%(\mathrm{v} / \mathrm{v})$ with absolute ethanol, and incubated at $27^{\circ} \mathrm{C}$ for a further $48 \mathrm{~h}$.

Transformation procedures. Competent cells of E. coli were prepared and transformed with plasmid DNA as described by Hopwood et al. (1985). Protoplasts of S. venequelae were prepared and transformed by the procedure of Aidoo et al. (1990). They were regenerated on $\mathrm{R} 5$ medium, and transformants were selected by overlaying the agar surface with soft nutrient agar containing sufficient thiostrepton to give a final plate concentration of $25 \mu \mathrm{g} \mathrm{ml}^{-1}$.

DNA manipulation. The general procedures described by Sambrook et al. (1989) were followed. Plasmid DNA was isolated from $E$. coli by the alkaline lysis method of Kieser (1984). Genomic DNA was isolated as described by Hopwood et al. (1985); phage DNA was isolated by the method of Meese et al. (1990). The genomic library of $S$. venezuelae DNA used initially consisted of $B g / \mathrm{II}$ fragments ligated to BamHI arms of $\lambda$ GEM-11 DNA (Promega). The second library contained sized $(9-23 \mathrm{~kb})$ fragments from a partial Sau3AI digest ligated to XhoI half-site arms of the vector.

DNA sequencing and sequence analysis. DNA fragments were subcloned in pBluescript II SK(+), and overlapping deletion clones were generated. Single-stranded DNA templates were isolated from cultures of E. coli TG1 phagemid transformants as described by Sambrook et al. (1989). They were sequenced by the dideoxy chain-termination method (Sanger $e t$ al., 1977) using Sequenase version 2.0 (USB) and $\left[\alpha-{ }^{35}\right.$ S $] \mathrm{dATP}$. Oligonucleotide primers were used for some regions, and to resolve anomalies where necessary, segments were resequenced with 7-deaza-dGTP in place of dGTP. Both strands of the $S$. venezuelae genomic DNA were sequenced, and the sequence was analysed with version 7.0 software developed by the Genetics Computer Group, Madison, WI, USA.

Hybridization. For plaque and colony hybridization, DNA was transferred to Hybond-N nylon membranes (Amersham) as described by Hopwood et al. (1985). Restriction enzyme digests were fractionated by electrophoresis in $0.7 \%$ agarose, and transferred to nylon membranes by the Southern procedure (Southern, 1975). DNA probes were labelled with $\left[\alpha-{ }^{32} \mathrm{P}\right] \mathrm{dCTP}$ or with digoxigenin (DIG)-dCTP by the random priming procedure. Hybridization was carried out at $65^{\circ} \mathrm{C}$ in a solution containing $5 \times$ SSPE $(1 \times$ SSPE is $0.18 \mathrm{M} \mathrm{NaCl}, 10 \mathrm{mM}$ sodium phosphate and $1 \mathrm{mM}$ EDTA, pH 7.7), $5 \times$ Denhardt's solution (Denhardt, 1966), 0.5\% SDS and sheared herring sperm DNA $\left(100 \mu \mathrm{g} \mathrm{ml}^{-1}\right)$. Membranes were washed twice at $65^{\circ} \mathrm{C}$ with the following solutions in sequence: $2 \times \mathrm{SSPE}$ containing $0 \cdot 1 \%$ SDS, $1 \times \mathrm{SSPE}$ containing $0.1 \% \mathrm{SDS}$, and $0 \cdot 1 \times \mathrm{SSPE}$ containing $0 \cdot 1 \%$ SDS. The stringency of the final wash should have removed DNA possessing less than $70 \%$ sequence identity with the probe. ${ }^{32} \mathrm{P}$-labelled DNA was detected by autoradiography; DIG-labelled DNA was detected by a chemiluminescence procedure (Boehringer-Mannheim).

Chromatographic analysis. Samples $(50 \mathrm{ml})$ of $S$. venezuelae culture filtrate were passed through $40 \mu \mathrm{m}$ particle size $\mathrm{C}_{18}$ reverse-phase silica columns ( $1 \mathrm{~g}$ Chromosep, Chromatographic Separations); the adsorbed jadomycin B was eluted with methanol. The eluate, concentrated to $0.2 \mathrm{ml}$, was chromatographed $(20 \mu \mathrm{l}$ sample) on a $4.6 \times 250 \mathrm{~mm}$ column of $5 \mu \mathrm{m}$ particle size $\mathrm{C}_{18}$ reverse-phase silica. The eluting solvent was a gradient of acetonitrile in $50 \%$ aqueous acetonitrile, with both solvents containing $0 \cdot 1 \%$ trifluoracetic acid (Ayer et al., 1991). Authentic jadomycin $B$ eluted from the column with a retention time of $11.6 \mathrm{~min}$; the concentration of jadomycin B in culture filtrates was quantified by comparing chromatographic peak areas with those given by reference solutions.

\section{RESULTS}

\section{Detection of act/-hybridizing DNA in S. venezuelae}

Samples of genomic DNA from $S$. venequelae strains ISP5230 and 13s (UC2374; see Table 1) were digested with $B a m \mathrm{HI}$, and the fragments separated by electrophoresis were hybridized at high stringency with $\mathrm{pIJ} 2345$, which contained an insert from the actI of $S$. coelicolor A3(2). The DNA from each strain showed a hybridizing fragment within the size range $(2 \cdot 0-2.8 \mathrm{~kb})$ of that detected by Malpartida et al. $(1987 \mathrm{a}, \mathrm{b})$ in $S$. venezuelae UC2374.

\section{Cloning of DNA hybridizing with actl and act/II}

Using pIJ2345 to screen a genomic DNA library containing fragments from a $B g / I I$ digest of $S$. venezuelae ISP5230 DNA in the replacement vector $\lambda$ GEM-11 yielded a recombinant phage containing a $1.8 \mathrm{~kb}$ $B g / \mathrm{II}-\mathrm{Sac}$ I fragment that hybridized with the probe. This fragment, which was located at one end of the insert DNA, was used to probe a second $S$. venezuelae ISP5230 library prepared in $\lambda$ GEM-11 from a partial Sau3AI digest. Three hybridizing $\lambda$ clones (LH2, LH7 and LH24) were isolated; the DNA from each was shown by Southern analysis to contain a $2.3 \mathrm{~kb} \mathrm{SacI}$ fragment that hybridized with the $1.8 \mathrm{~kb}$ probe. Reprobing the same Southern blots with the $1 \cdot 1 \mathrm{~kb}$ insert excised from $\mathrm{pIJ} 2346$ located 1.0 and $0.3 \mathrm{~kb} \mathrm{SacI}$ fragments that hybridized at high stringency. A restriction map of the region (Fig. 2a) showed that the $2.3,1.0$ and $0.3 \mathrm{~kb}$ SacI fragments hybridizing to actI and actIII are adjacent. To isolate the $2.3 \mathrm{~kb} \mathrm{SacI}$ fragment, a mixture of the 2.3 and $2.4 \mathrm{~kb}$ fragments from a $S a c I$ digest of DNA from $\lambda$ clone LH7 was excised from an electrophoresis gel and subcloned in $\mathrm{pHJL400}$. The plasmid mixture was used to transform $E$. coli, and transformants containing the $2.3 \mathrm{~kb}$ fragment were identified by colony hybridization.

\section{Sequence analysis}

The region of $S$. venezuelae ISP5230 DNA containing the $2 \cdot 3,1.0$ and $0.3 \mathrm{~kb} \mathrm{SacI}$ fragments hybridizing with actI and actIII was subcloned from the insert in $\lambda$ clone LH7. 
(a)

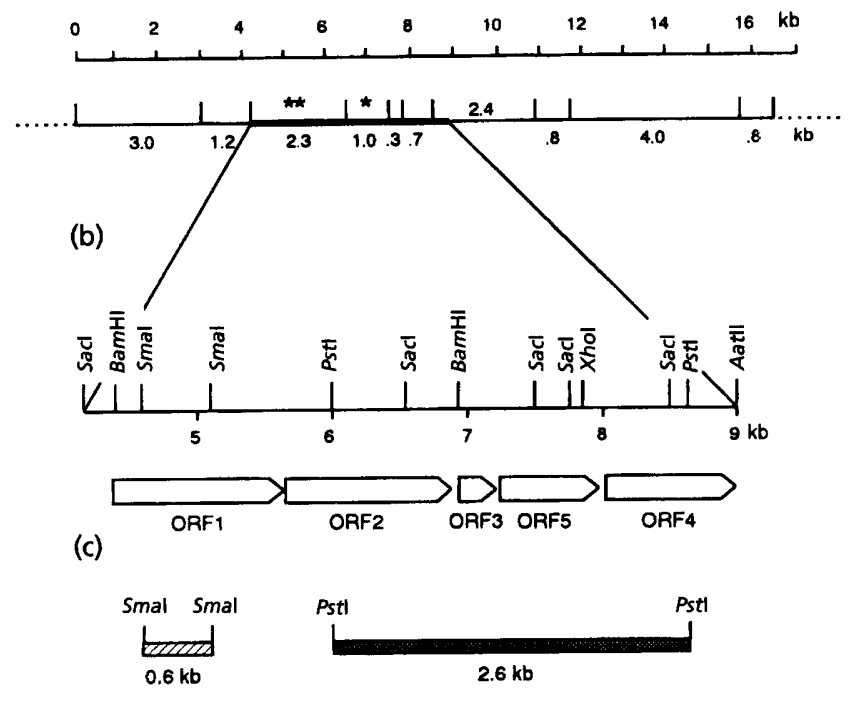

Fig. 2. (a) A Sacl restriction map of the S. venezuelae ISP5230 DNA insert in $\lambda$ clone $\mathrm{LH} 7$. The 2.3 and $1.0 \mathrm{~kb}$ regions hybridizing with actl and actllI are indicated with double and single asterisks, respectively. The $4.8 \mathrm{~kb}$ region sequenced is shown as a thickened line. (b) An expansion of the $4.8 \mathrm{~kb}$ region showing significant restriction sites; pointed bars represent the extent and direction of the five ORFs detected. (c) The rectangular bars identify the two fragments used in gene disruption experiments.

Overlapping fragments $(2.3 \mathrm{~kb} S a c \mathrm{I}, 2.6 \mathrm{~kb}$ Pst I and $2.4 \mathrm{~kb} S a c \mathrm{I}$; see Fig. 2a) were inserted individually into pBluescript II SK(+), and sequenced (Fig. 3). Analysis of the data with the FRAME program (Bibb et al., 1984) showed five ORFs, all transcribed in the same direction (see Fig. 2b). Their designations as ORFs 1-5 are based on the similarity of their deduced amino acid sequences to those of ORFs 1-5 in streptomycete gene clusters for type-II PKSs (Hopwood \& Sherman, 1990). The translational start site for each ORF was predicted from the location of a potential start codon closely preceded by a plausible ribosome-binding site (RBS). The $3^{\prime}$ end of ORF1 overlaps by 4 bp the predicted start codon (ATG) of ORF2, which begins at nucleotide 1412 and is preceded by a likely RBS located within the ORF1 sequence. This type of organization suggests translational coupling, and occurs frequently in ORFs 1 and 2 of other PKSs. ORF2 is separated from ORF3 by 42 bp of non-coding DNA, ORF3 and ORF5 are $73 \mathrm{bp}$ apart, while $39 \mathrm{bp}$ of noncoding DNA separates ORF4 and ORF5.

\section{Deduced functions}

The deduced amino acid sequence of ORF1 is strikingly similar to sequences deduced for ORF1 in the PKS gene clusters for actinorhodin in S. coelicolor A3(2) (FernándezMoreno et al., 1992), granaticin in S. violaceoruber (Sherman et al., 1989), tetracenomycin C in Streptomyces glaucescens (Bibb et al., 1989), an unidentified polyketide-derived metabolite in Streptomyces cinnamonensis (Arrowsmith et al., 1992) and the whiE spore pigment in S. coelicolor A3(2)
(Davis \& Chater, 1990). Over a region of 420 amino acids, the polypeptide sequences exhibit more than $60 \%$ identity. The similarity is particularly strong (almost $100 \%$ identity) in the region of the presumed active site, where the cysteine and serine residues responsible for substrate attachment are located (Fig. 4a). The deduced amino acid sequence of ORF 2 shows $60 \%$ identity to the sequences deduced for ORF2 in known PKS clusters. The ORF2 from S. venezuelae ISP5230 also resembles other ORF2s in being very similar in sequence to ORF1, but lacking the two active site motifs. McDaniel et al. (1993) have recently proposed that the protein encoded by ORF2 in the act, gra and $t \mathrm{~cm}$ PKS clusters influences the chain length of the PKS product.

The deduced product of ORF3 is a relatively small protein of 90 amino acids; its amino acid sequence shows $66 \%$ identity to the sequence deduced from ORF3 of the S. cinnamonensis $\mathrm{PKS}$, and somewhat lower identity $(40-50 \%)$ to the sequence of acyl carrier proteins (ACPs) of fatty acid and polyketide synthases. This similarity includes a conserved motif around the serine residue to which the pantetheinyl cofactor is presumably attached (Fig. 4b). The products of ORF1, ORF2 and ORF3 would be expected to form an enzyme complex able to condense acyl building units into a polyketide chain; thus the function analysis of this region indicates that the $2 \cdot 3 \mathrm{~kb} \mathrm{SacI}$ fragment from $S$. venezuelae encodes part of a PKS gene cluster.

The deduced product of ORF5 showed $82 \%$ sequence identity with the deduced products of ORF5 from the ' mon' PKS gene cluster of $S$. cinnamonensis (Arrowsmith $e$ t al., 1992) and $60 \%$ identity to the ORF5 products from $S$. coelicolor A3(2) (Hallam et al., 1988), and S. violaceoruber (Sherman et al., 1989). It also shares with these proteins the conserved sequence motif Gly-X-Gly-X-X-[Gly/Ala] characteristic of nucleotide binding proteins (Fig. 4c). Thus ORF5 probably encodes a ketoreductase that catalyses the reduction of a specific keto group in the polyketide to a hydroxyl group that is subsequently eliminated during chain assembly.

Strong overall similarity ( $59 \%$ identity) was also apparent between the amino acid sequences deduced from ORF4 of S. venezuelae ISP5230 and S. cinnamonensis, and only slightly less ( $45 \%$ identity) between the ORF4 products from $S$. venezuelae and the act and gra PKS gene clusters. The ORF4 product was less similar to ORFVI in the whiE cluster, and resembled only the $\mathrm{N}$-terminal half of ORF4 in the $t \mathrm{~cm}$ PKS gene cluster, but overall the results indicated that ORF4 in each cluster encodes a protein with a similar function, believed to be the correct cyclization of a region in the polyketide backbone (Zhang et al., 1990).

\section{Gene disruption}

A $0.6 \mathrm{~kb} S m a \mathrm{I}$ fragment of $S$. venequelae DNA internal to ORF1 (see Fig. 2c) was subcloned in the unique $S m a$ site

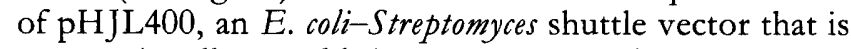
segregationally unstable in streptomycetes because it lacks 
SaCI

GAGCTCATCGAGCGGGCCAAGACCGACCCCCGCTTCGTGGGCATCAGCGAGGACCTGAAG CCGTTCATCGAGGCCTACGACCCGGCCACCTGGCGCTCGCCCGCCGACGCCATGGCCACC RBS ORF1--->

CGCTTCTACAACTGGGAGGCGAACGCGTGACCGCGCGACGCGTCGTCATCACCGGCATCG BamHI

AGGTCCTCGCCCCCGGTGGCACCGGATCCAAGGCCTTCTGGAACCTGCTCAGCGAGGGCC $\begin{array}{llllllllllllllllllll}V & I & A & P & G & G & T & G & S & K & A & F & W & N & L & L & S & E & G & R\end{array}$

GCACGGCCACCCGGGGCATCACCTTCTTCGACCCGACGCCGTTCCGCTCCCGGGTCGCCG $\begin{array}{llllllllllllllllllllllllll}T & A & T & R & G & I & T & F & F & D & P & T & P & F & R & S & R & V & A & A\end{array}$ CCGAGATCGACTTCGACCCGGAGGCCCACGGCCTCAGCCCGCAGGAGATCCGCCGCATGG $\begin{array}{llllllllllllllllllll}E & I & D & F & D & P & E & A & H & G & L & S & P & Q & E & I & R & R & M & D\end{array}$ ACCGGGCCGCCCAGTTCGCGGTGGTCGCCGCGCGCGCCGTCGCCGACAGCGGCATCGACC $\begin{array}{llllllllllllllllllll}R & A & A & Q & E & A & V & V & A & A & R & A & V & A & D & S & G & I & D & L\end{array}$ TGGCCGCCCACGACCCGTACCGCGTCGGCGTCACCGTCGGCAGCGCCGTCGGCGCCACCA $\begin{array}{llllllllllllllllllll}A & A & H & D & P & Y & R & V & G & V & T & V & G & S & A & V & G & A & T & M\end{array}$ TGGGCCTCGACGAGGAGTACCGGGTCGTCAGCGACGGCGGCCGGCTCGACCTCGTCGACC $\begin{array}{llllllllllllllllllll}G & L & D & E & E & Y & R & V & V & S & D & G & G & R & L & D & L & V & D & H\end{array}$ ACGCCTACGCGGTGCCGCACCTCTACGACTACATGGTGCCCAGCTCCTTCTCCGCCGAGG $\begin{array}{llllllllllllllllllll}A & Y & A & V & P & H & L & Y & D & Y & M & V & P & S & S & F & S & A & E & V\end{array}$ TCGCCTGGGCCGTCGGCGCCGAGGGCCCCAACACCGTGGTCTCCACCGGCTGCACCTCCG $\begin{array}{llllllllllllllllllll}A & W & A & V & G & A & E & G & P & N & T & V & V & S & T & G & C & T & S & G\end{array}$ GCCTCGACTCCGTCGGCTACGCGCGTGGGGAGCTGATCCGCGAGGGCTCCGCCGACGTCA $\begin{array}{llllllllllllllllllll}L & D & S & V & G & Y & A & R & G & E & L & I & R & E & G & S & A & D & V & M\end{array}$ TGATCGCCGGTTCCTCGGACGCCCCGATCTCCCCGATCACGATGGCCTGCTTCGACGCCA $\begin{array}{llllllllllllllllllll}I & A & G & S & S & D & A & P & I & S & P & I & T & M & A & C & F & D & A & I\end{array}$ TCAAGGCGACCACCAACCGGTACGACGACCCGGCGCACGCCTCCCGGCCCTTCGACGGCA $\begin{array}{lllllllllllllllllllll}K & A & T & T & N & R & Y & D & D & P & A & H & A & S & R & P & F & D & G & T\end{array}$ CCCGCAACGGCTTCGTGCTCGGCGAGGGCGCGGCCGTCTTCGTCCTGGAGGAGCTGGAGA $\begin{array}{llllllllllllllllllll}R & N & G & F & V & L & G & E & G & A & A & V & F & V & L & E & E & L & E & S\end{array}$ SmaI

GCGCCCGGGCCCGCGGCGCCCACATCTACGCCGAGATCGCCGGCTACGCCACCCGCAGCA $\begin{array}{llllllllllllllllllll}A & \bar{R} & A & R & G & A & H & I & Y & A & E & I & A & G & Y & A & T & R & S & N\end{array}$ ACGCGTACCACATGACCGGTCTGCGGCCGGACGGCGCGGAGATGGCGGAGGCGATCCGGG $\begin{array}{llllllllllllllllllll}A & Y & H & M & T & G & L & R & P & D & G & A & E & M & A & E & A & I & R & V\end{array}$ TCGCGCTCGACGAGGCGCGGATGAACCCCACCGAGATCGACTACATCAACGCGCACGGCT $\begin{array}{llllllllllllllllllll}A & L & D & E & A & R & M & N & P & T & E & I & D & Y & I & N & A & H & G & S\end{array}$ CCGGCACCAAGCAGAACGACCGCCACGAGACCGCAGCGTTCAAGAAGAGCCTCGGGGACC $\begin{array}{llllllllllllllllllll}G & T & K & Q & N & D & R & H & E & T & A & A & F & K & K & S & L & G & D & H\end{array}$ ACGCGTACCGCACCCCGGTCAGCTCCATCAAGTCGATGGTCGGGCACTCCC TCGGTGCCA $\begin{array}{llllllllllllllllllll}A & Y & R & T & P & V & S & S & I & K & S & M & V & G & H & S & L & G & A & I\end{array}$ TCGGCTCCATCGAGATCGCCGCCTCGGCCCTGGCCATGGAGCACAACGTGGTCCCGCCGA $\begin{array}{llllllllllllllllllll}G & S & I & E & I & A & A & S & A & L & A & M & E & H & N & V & V & P & P & T\end{array}$ CGGGCAACCTGCACACCCCGGACCCCGAGTGCGACCTGGACTACGTCCGCTCGTGCCGCG $\begin{array}{lllllllllllllllllllllllllll}G & N & L & H & T & P & D & P & E & C & D & L & D & Y & V & R & S & C & R & E\end{array}$ AGCAGCTCACGGACTCGGTCCTGACCGTCGGCAGCGGATTCGGCGGCTTCCAGAGCGCCA $\begin{array}{llllllllllllllllllllllllllllll}Q & L & T & D & S & V & L & T & V & G & S & G & F & G & G & F & Q & S & A & M\end{array}$ RBS ORF2 $--->$

TGGTCCTGGCCCGTCCCGAGAGGAAGATCGCATGAGCGCGTCCGTGGTGGTGACCGGCCT $\begin{array}{llllllllllllllllllll}V & L & A & R & P & E & \bar{R} & \bar{K} & I & A & M^{*} & S & A & S & V & V & V & T & G & I\end{array}$ CGGTGTCGCCGCACCCAACGGCCTGGGCCGCGAGGACTTCTGGGCCTCGACCC TCGGCGG $\begin{array}{llllllllllllllllllll}G & V & A & A & P & N & G & L & G & R & E & D & F & W & A & S & T & I & G & G\end{array}$ GAAGAGCGGCATCGGCCCGCTCACCCGCTTCGACCCCACCGGCTACCCGGCGCGCCTCGC $\begin{array}{lllllllllllllllllllll}K & S & G & I & G & P & L & T & R & F & D & P & T & G & Y & P & A & R & L & A\end{array}$ CGGCGAGGTGCCCGGCTTCGCCGCCGAGGAGCACCTGCCGAGCCGGCTGCTGCCGCAGAC $\begin{array}{llllllllllllllllllll}G & E & V & P & G & F & A & A & E & E & H & L & P & S & R & L & L & P & Q & T\end{array}$ CGACCGGATGACCCGCCTCGCGCTGGTCGCCGCGGACTGGGCGCTGGCCGACGCGGGCGT $\begin{array}{llllllllllllllllllll}D & R & M & T & R & L & A & L & V & A & A & D & W & A & L & A & D & A & G & V\end{array}$ CCGCCCCGAGGAGCAGGACGACTTCGACATGGGCGTGGTCACGGCCAGCGCCTCCGGCGG $\begin{array}{llllllllllllllllllll}R & P & E & E & Q & D & D & F & D & M & G & V & V & T & A & S & A & S & G & G\end{array}$ PstI

CTTCGAGTTCGGCCAGGGCGAGCTGCAGAAGCTGTGGAGCCAGGGCAGCCAGTACGTCAG 1800 $\begin{array}{llllllllllllllllllll}F & E & F & G & Q & G & E & \bar{L} & Q & K & L & W & S & Q & G & S & Q & Y & V & S\end{array}$ $B g l$ II

CGCGTACCAGTCCTTCGCCTGGTTCTACGCCGTCAACAGCGGCCAGATCTCCATCCGCAA $\begin{array}{lllllllllllllllllllllllll}A & Y & Q & S & F & A & W & F & Y & A & V & N & S & G & Q & I & S & I & R & N\end{array}$ CGGCATGAAGGGCCCCAGCGGCGTGGTCGTCAGCGACCAGGCCGGCGGTCTGGACGCCGT

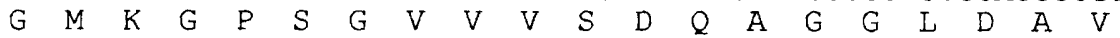

120

180

240

300

360

420

480

540

600

660

720

780

840

900

960

1020

1080

1140

1200

1260

1320

1380

1440

1500

1560

1620

1680

1740

1860

1920

Fig. 3. For legend see page 3385. 
CGCGCAGGCCCGCCGACAGATCCGCAAGGGCACCCGGCTCATCGTCTCCGGTGGCGTCGA

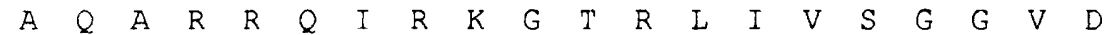
CGCCTCGCTCTGCCCCTGGGGCTGGGTGGCGCACGTCGCCTCCGACCGGCTCAGCACCAG $\begin{array}{llllllllllllllllllll}A & S & I & C & P & W & G & W & V & A & H & V & A & S & D & R & I & S & T & S\end{array}$ CGAGGAGCCCGCCCGGGGCTACCTGCCCTTCGACCGCGAAGCCCAGGGCCACGTGCCCGG $\begin{array}{llllllllllllllllllll}E & E & P & A & R & G & Y & L & P & E & D & R & E & A & Q & G & H & V & P & G\end{array}$ CGAGGGTGGGGCGATCCTCGTCATGGAGGCCGCCGAGGCGGCCCGGGAGCGCGGGGCCCG $\begin{array}{llllllllllllllllllll}E & G & G & A & I & L & V & M & E & A & A & E & A & A & R & E & R & G & A & R\end{array}$ GATCTACGGCGAGATCGCCGGATACGGCTCCACCTTCGACCCCCGGCCGGGCAGCGGGCG $\begin{array}{llllllllllllllllllll}I & Y & G & E & I & A & G & Y & G & S & T & F & D & P & R & P & G & S & G & R\end{array}$ CGAGCCCGGCCTGCGCAAGGCCATCGAACTCGCCCTGGCCGACGCCGGAGCGGCACCCGG $\begin{array}{lllllllllllllllllllllll}E & P & G & L & R & K & A & I & E & L & A & L & A & D & A & G & A & A & P & G\end{array}$ SaCI

TGACATCGACGTCGTCTTCGCGGACGCGGCCGCCGTCCCCGAGCTCGACCGCGTCGAGGC $\begin{array}{llllllllllllllllllllllll}D & I & D & V & V & F & A & D & A & A & A & V & P & \bar{E} & L & D & R & V & E & A\end{array}$ CGAGGCCCTCAACGCCGTCT TCGGCACCGGCGCCGTCCCGGTCACCGCGCCCAAGACGAT $\begin{array}{llllllllllllllllllll}E & A & L & N & A & V & E & G & T & G & A & V & P & V & T & A & P & K & T & M\end{array}$ GACCGGCCGGCTGTACTCCGGCGCCGCGCCGCTCGACCTGGCCGCCGCGTTCCTCGCGAT $\begin{array}{lllllllllllllllllllll}T & G & R & L & Y & S & G & A & A & P & L & D & L & A & A & A & E & L & A & M\end{array}$ GGACGAGGGCGTCATCCCGCCCACCGTCAACGTCGAGCCGGACGCCGCGTACGGCCTCGA $\begin{array}{llllllllllllllllllll}D & E & G & V & I & P & P & T & V & N & V & E & P & D & A & A & Y & G & I & D\end{array}$ CCTGGTCGTCGGCGGGCCCCGTACCGCCGAGGTGAACACCGCCCTGGTGATCGCCCGCGG $\begin{array}{lllllllllllllllllllll}I & V & V & G & G & P & R & T & A & E & V & N & T & A & L & V & I & A & R & G\end{array}$ TCACGGCGGCTTCAACTCCGCGATGGTCGTCCGTTCCGCGAACTGACCTTTCCCCCGCAG $\begin{array}{llllllllllllllll}H & G & G & F & N & S & A & M & V & V & R & S & A & N\end{array}$ RBS ORF3--->

TACCTCACAGTCACCCAGGAGAAGAACCATGAGCAGCAAGACCTTCACCCTCGACGACCT BamH I $\begin{array}{lllllllllllllll}M & S & S & K & T & F & T & L & D & D & L\end{array}$ CAAGCGGATCCTGCGCGAGGGCGCCGGCGCCGACGAGGGCGTCGACCTCGACGGCGACAT $\begin{array}{llllllllllllllllllllllll}K & R & I & L & R & E & G & A & G & A & D & E & G & V & D & L & D & G & D & I\end{array}$ CCTCGACACCCACTTCGAGACGCTCGGCTACGAGTCGCTCGCCCTGCTGGAGACCGGCAG $\begin{array}{llllllllllllllllllll}L & D & T & H & F & E & T & L & G & Y & E & S & L & A & L & L & E & T & G & S\end{array}$ CCGCATCGAGCGCGAGTACTCCATCACCCTCGACGACGACGTGCTGTCCGACGCCGACAC $\begin{array}{lllllllllllllllllllll}R & I & E & R & E & Y & S & I & T & L & D & D & D & V & L & S & D & A & D & T\end{array}$ CCCGCGCGCCCTCATCGAGGCCGTCAACGCGCACCTGTCGGCCGTCGCCGCCGCCTGACC $\begin{array}{lllllllllllllllllll}\mathrm{P} & \mathrm{R} & \mathrm{A} & \mathrm{L} & \mathrm{I} & \mathrm{E} & \mathrm{A} & \mathrm{V} & \mathrm{N} & \mathrm{A} & \mathrm{H} & \mathrm{L} & \mathrm{S} & \mathrm{A} & \mathrm{V} & \mathrm{A} & \mathrm{A} & \mathrm{A} & \\ \end{array}$

CACCCGACCGACACCGGCGCCCGTACCCGCCGCCGTACCGCCGCCCCCTGGCAßAGAAGA ORF5--->

GACGACACCGCATGTCCCAGCAGGAGAAGCAGGAGAAGAGGGTCGCCCTCGTCACCGGAG $\begin{array}{llllllllllllllllllllllll}M & S & Q & Q & E & K & Q & E & K & R & V & A & L & V & T & G & A\end{array}$ CCACCAGTGGCATCGGCCTCGCCGTCGCCCGGCTCCTGGCGTCCCAGAACCACCGGGTGT $\begin{array}{llllllllllllllllllllllll} & S & G & I & G & L & A & V & A & R & L & L & A & S & Q & N & H & R & V & E\end{array}$ TCCTCGGTGCCCGCAACGCCGAGAACGTCGCCGCCACCGTCAAGCAGCTCCAGGACGAGG $\begin{array}{lllllllllllllllllllllllllllll}L & G & A & R & N & A & E & N & V & A & A & T & V & K & Q & L & Q & D & E & G\end{array}$ GCCTTGAGGTCGACGGCACCACCCTCGACGTGCGCTCCGGCGAGGACGTCAAGGCCTTCG

$\begin{array}{llllllllllllllllllll}i & E & V & D & G & T & T & L & D & V & R & S & G & E & D & V & K & A & F & V\end{array}$ SacI

TCCAGGCCGCCGTCGACCGCTTCGGCACCGTCGAGCTCCTCGTGAACAACGCGGGCCGCA $\begin{array}{llllllllllllllllllllllllllllllll}Q & A & A & V & D & R & E & G & T & V & E & \bar{L} & L & V & N & N & A & G & R & S\end{array}$ GCGGCGCGGGCGTCACCGCCGACATCGCCGACGAGCTGTGGAACGACGTCATCGACACCA $\begin{array}{llllllllllllllllllll}G & A & G & V & T & A & D & I & A & D & E & L & W & N & D & V & I & D & T & N\end{array}$ ACCTCAACTGCGTCTTCCGGCTCACCCGCGAGGCCCTGACCACCGGCGGCATGCGCGAGA $\begin{array}{lllllllllllllllllllll}I & N & C & V & F & R & L & T & R & E & A & I & T & T & G & G & M & R & E & K\end{array}$ AGTCCCGCGGCCGGATCATCAACATGGCCTCGACCGCCGGCAAGCAGGGCGTCGTCCTCG $\begin{array}{llllllllllllllllllll}S & R & G & R & I & I & N & M & A & S & T & A & G & K & Q & G & V & V & L & G\end{array}$ GCGCCCCCTACTCGGCCTCGAAGCACGGCGTCGTCGGCTTCACCAAGGCCCTCGGCAACG $\begin{array}{llllllllllllllllllll}A & P & Y & S & A & S & K & H & G & V & V & G & F & T & K & A & L & G & N & \bar{E}\end{array}$ SaCI

AGCTCGCCCCGACCGGCATCACCGTCAACGCGGTCTGCCCCGGTTACGTCGAGACGCCGA $\begin{array}{llllllllllllllllllll}L & A & P & T & G & I & T & V & N & A & V & C & P & G & Y & V & E & T & P & M\end{array}$ TGGCCCAGCGCGTCCGCCAGGGCTACGCCGCCGCGTACGAGACCTCCGAGGACGCCATCC $\begin{array}{llllllllllllllllllll}A & Q & R & V & R & Q & G & Y & A & A & A & Y & E & T & S & E & D & A & I & \bar{L}\end{array}$ XhoI

TCGAGAAGTTCCAGTCGAAGATCCCGCTCGGCCGC TACTCCACGCCCGAGGAGGTCGCCG \begin{tabular}{llllllllllllllllllll}
\hline & $E$ & $E$ & $Q$ & $S$ & $K$ & $I$ & $P$ & $L$ & $G$ & $R$ & $Y$ & $S$ & $T$ & $P$ & $E$ & $E$ & $V$ & $A$ & $G$
\end{tabular} GTCTCGTCGGCTACCTGGCCTCCGACACCGCGGCCTCCATCACCTCGCAGGCGCTCAACG $\begin{array}{llllllllllllllllllll}\mathrm{L} & V & G & Y & L & A & S & D & T & A & A & S & I & T & S & Q & A & L & N & V\end{array}$ TCTGCGGCGGCCTGGGCAACTTCTGATCCCCGCACCCCCTCTCGCACCGTCCCGAGGAGT 3840 $C \quad G \quad G \quad L \quad G \quad N \quad F$ *

1980

\section{Fig. 3. For legend see facing page.}




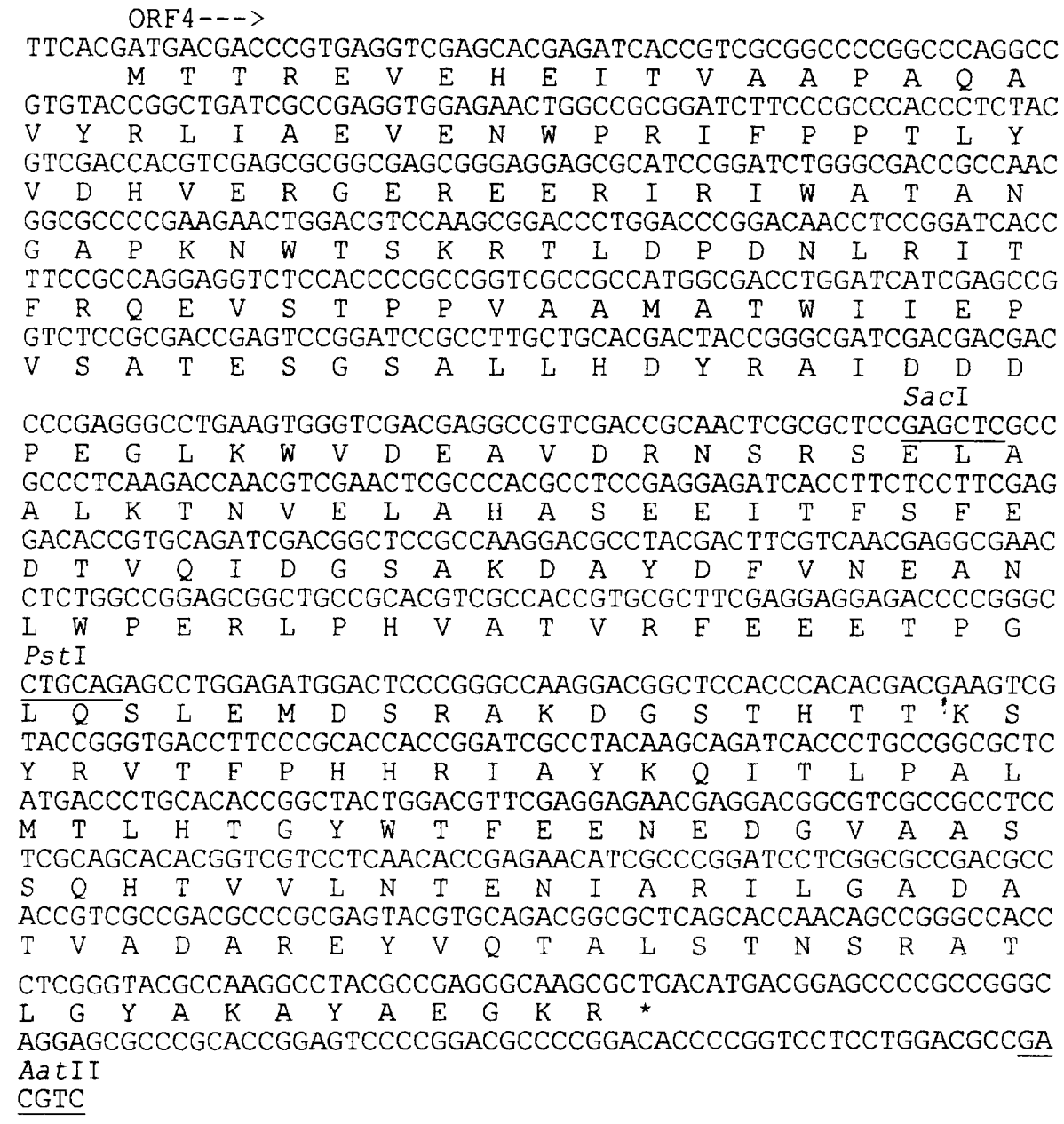

3900

3960

4020

4080

4140

4200

4260

4320

4380

4440

4500

4560

4620

4680

4740

4800

4860

4864

Fig. 3. Nucleotide and deduced amino acid sequences of the $4.8 \mathrm{~kb}$ segment of DNA containing ORFs $1-5$. Putative ribosome-binding sites and significant restriction enzyme recognition sequences are underlined. Translational start codons are identified as the beginning of ORFs; asterisks identify stop codons.

the partition function of the SCP2* parent (Larson \& Hershberger, 1986). The recombinant plasmid (pJV62) isolated from $E$. coli TG1 transformed $S$. venezuelae ISP5230 to thiostrepton resistance (the marker in pHJL400 used for selection) with very low efficiency. This difficulty was exacerbated by a relatively high rate of spontaneous mutation to thiostrepton resistance. All presumptive integrants selected on thiostrepton after passage of 100 putative Thio $^{\mathbf{R}}$ transformants through thiostrepton-free medium to promote plasmid loss failed to hybridize to $\mathrm{pHJL} 400$. However, the efficiency with which pJV62 transformed S. venezuelae ISP5230 could be markedly improved by isolating the plasmid from E. coli ET12567 (dam $\left.{ }^{-} d \mathrm{~cm}^{-} b s d M^{-}\right)$(MacNeil et al., 1992), thereby avoiding the restriction barrier to methylated DNA apparently present in this and other streptomycetes (MacNeil, 1988). Transformation of S. venezuelae ISP5230 with pJV62 then yielded approximately 70 Thio $^{\mathbf{R}}$ colonies per $\mu \mathrm{g}$ of plasmid DNA. Extraction and electrophoresis of DNA from 10 of these showed plasmid clearly present in two. However, the remaining eight harboured free plasmid in low concentration, since transformation of $E$. coli TG1 with extracts gave, in each case, ampicillinresistant colonies containing pJV62. An attempt to eliminate free $\mathrm{pJV} 62$ from 10 Thio $^{\mathrm{R}}$ transformants by two rounds of subculturing in the absence of thiostrepton selection, and then to select strains in which pJV62 had integrated into the $S$. venequelae chromosome through a single cross-over between the $0.6 \mathrm{~kb} \mathrm{SmaI} \mathrm{fragment} \mathrm{and}$ the homologous DNA region on the chromosome was not successful. Southern analysis of the subcultured colonies using pHJL400 and the $2.3 \mathrm{~kb}$ SacI fragment as probes detected free pJV62 in each culture and showed that the chromosomal PKS gene was still intact.

Transformants containing integrated vector DNA were obtained by using a larger homologous insert. Because unfavourable secondary structure might also have contributed to the failure of pJV62 to yield stable integrants, the $2.6 \mathrm{~kb}$ Pst $\mathrm{I}-P_{s t \mathrm{I}}$ insert in the new plasmid (pJV63) was from a different region of the PKS gene cluster; see Fig. 2c). It was ligated into the PstI site of $\mathrm{pHJL400, \text {and }}$ 
(a)

actI ORF 1

gra ORF1

tcm ORF1

whiE ORFIII

S. cinnamonensis ORF 1

S. venezuelae ORF1 (b)

actl ORF3

gra ORF3

tcm ORF3

whiE ORFV

S. cinnamonensis ORF

S. venezuelae ORF3

(c)

actIII ORF5

gra ORF5

S. cinnamonensis ORF5

S. venezuelae ORF5

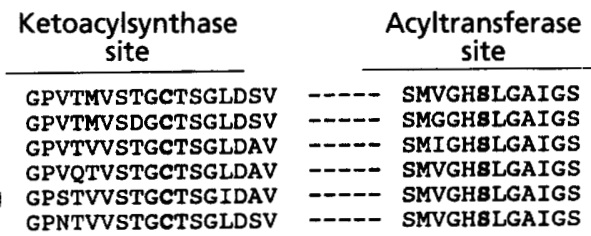

Fig. 4. Alignment by the PILEUP program (Genetics Computer Group, University of Wisconsin, Madison, WI, USA) of segments of the amino acid sequences deduced from ORFs in the $S$. venezuelae ISP5230 and other streptomycete PKS gene clusters (see text for references). (a) ORF1 sequences around the presumed $\beta$-ketoacylsynthase active site cysteine and the presumed acyltransferase active site serine. (b) ORF3 sequences around the active site serine in putative ACPs. (c) ORF5 sequences around the presumed NAD(P)-binding domain of $\beta$ ketoreductases.

unmethylated plasmid DNA isolated from an E. coli ET12567 transformant was used to transform S. venezuelae ISP5230; approximately $30 \mathrm{Thio}^{\mathrm{R}}$ colonies were obtained per $\mu \mathrm{g}$ of plasmid DNA. Agarose gel electrophoresis and Southern hybridization with $\mathrm{pHJL} 400$ as a probe failed to detect free plasmid in DNA extracted from the transformants, but only two of five samples examined gave hybridization signals. In each of these, the signal corresponded to chromosomal DNA in mobility. Integration of pJV63 into the two transformants VS651 and VS652 was confirmed by Southern analysis of restriction digests of genomic DNA using the $2.6 \mathrm{~kb}$ Pst I-PstI fragment and $\mathrm{pHJL} 400$ as probes. Wild-type DNA digested with $M l u \mathrm{I}$ or EcoR1 and probed with the $2.6 \mathrm{~kb}$ fragment gave signals at $7.0 \mathrm{~kb}$ and approximately $30 \mathrm{~kb}$, respectively. In contrast, VS651 and VS652 digested with EcoRI gave signals at 5.0, 8.4 and about $35 \mathrm{~kb}$, and after digestion with $M l u \mathrm{I}$ at above $30 \mathrm{~kb}$ (Fig. 5a). When the membrane was stripped to remove the probe and rehybridized with $\mathrm{pHJL} 400$, each of the signals in the wild-type DNA digests, and that at $5.0 \mathrm{~kb}$ in the EcoRI digests of the integrants were absent. The sizes and intensities of the signals, and the results with the different probes, were all consistent with integration into the $2.6 \mathrm{~kb}$ region of the chromosome of at least three copies of pJV63 (Fig. 5b).

No differences between the wild type and VS651 or VS652 were detected in growth, the abundance of spores on MYM medium, or the blue-green pigmentation of the spores. In contrast, production of jadomycin B in strains VS651 and VS652 was severely depressed. Whereas (a)

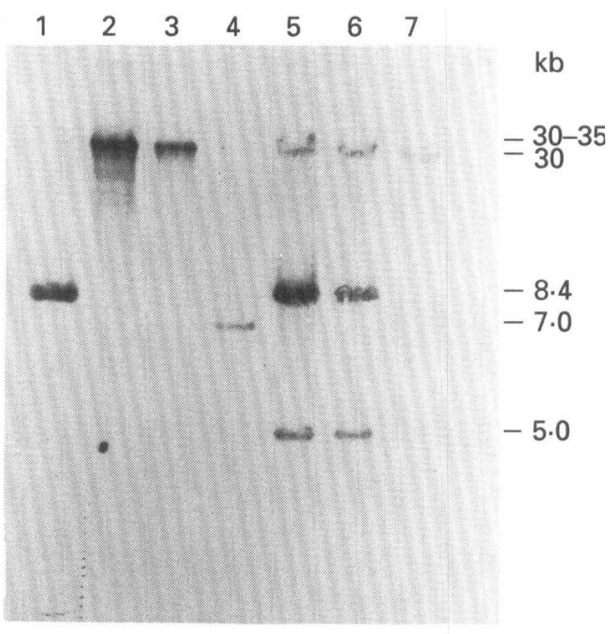

(b)

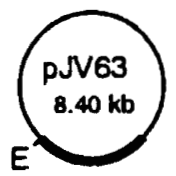

ISP5230

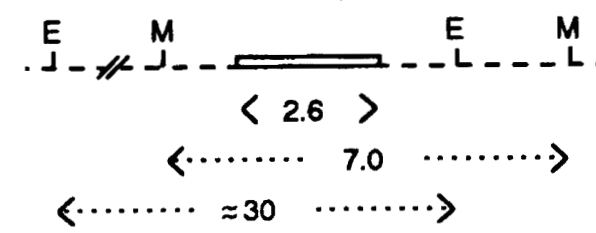

3 tandem insertions by homologous recombination

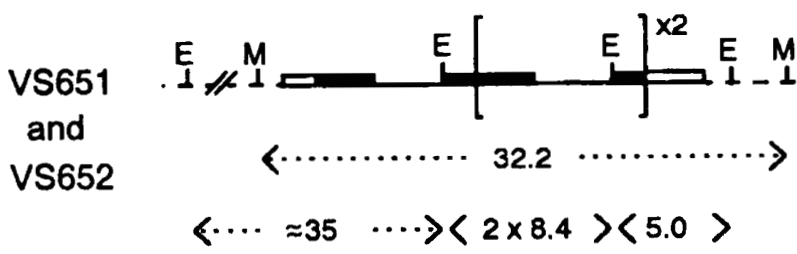

Fig. 5. Southern hybridization of genomic DNA from $S$. venezuelae ISP5230 and transformants VS651 and VS652; the $2.6 \mathrm{~kb}$ Pstl-Pstl fragment from $\lambda$ LH7 was used as the probe. (a) Autoradiogram of labelled DNA fragments after hybridization. Lanes: 1, EcoRI-digested pJV63; 2, Mlul-digested VS652 DNA; 3, Mlul-digested VS651 DNA; 4, Mlul-digested ISP5230 DNA; 5, EcoRI-digested VS652 DNA; 6, EcoRI-digested VS651 DNA; 7 , EcoRl-digested ISP5230 DNA. Fragment sizes were measured against HindIII-digested $\lambda$ DNA. (b) Schematic diagram postulating tandem integration of three copies of pJV63 into the $S$. venezuelae chromosome and accounting for the products of digestion with Mlul (M) and EcoRI (E). The numbers are restriction map distances in $\mathrm{kb}$.

cultures of the wild type and of control strains transformed with $\mathrm{pHJL} 400$ or pJV62 showed strong orange pigmentation in the supernatant broth $48 \mathrm{~h}$ after ethanol 
treatment, VS651 and VS652 cultures remained unpigmented even after $72 \mathrm{~h}$. Extraction and HPLC analysis of the cultures confirmed the presence of jadomycin B at the expected concentration (30 $\mathrm{mg} \mathrm{l}^{-1}$; Doull et al., 1993) in the wild-type and control cultures. In cultures of VS651 and VS652, a small peak corresponding to jadomycin B represented $6 \%$ of that in the positive controls. A control not treated with ethanol gave no detectable peak for jadomycin B.

\section{DISCUSSION}

Cloning and sequence analysis of the fragment of $S$. venezuelae ISP5230 DNA that hybridizes with actI from $S$. coelicolor A3(2) has confirmed the initial indication from hybridizations by Malpartida et al. $(1987 \mathrm{a}, \mathrm{b})$ that $S$. venezulae possesses genes for the biosynthesis of polyketide-derived metabolites. The results add yet further evidence of the value of act probes in detecting strains producing type-II polyketide metabolites. The $S$. venezuelae strain probed by Malpartida et al. (1987a, b) differs from ISP5230 in several characteristics (Ahmed \& Vining, 1983; Stuttard, 1982), but both fall within the species venezuelae (Stuttard, 1982), and both are known to produce chloramphenicol (Vining \& Westlake, 1984). The ISP5230 strain has only recently been reported to form the polyketide-derived jadomycins (Ayer et al., 1991), and indeed the earlier isolation of mutants blocked in chloramphenicol production (Doull et al., 1985) was consistent with this antibiotic being the sole active product; failure to detect the jadomycins is attributed in a large measure to the unusual culture conditions required

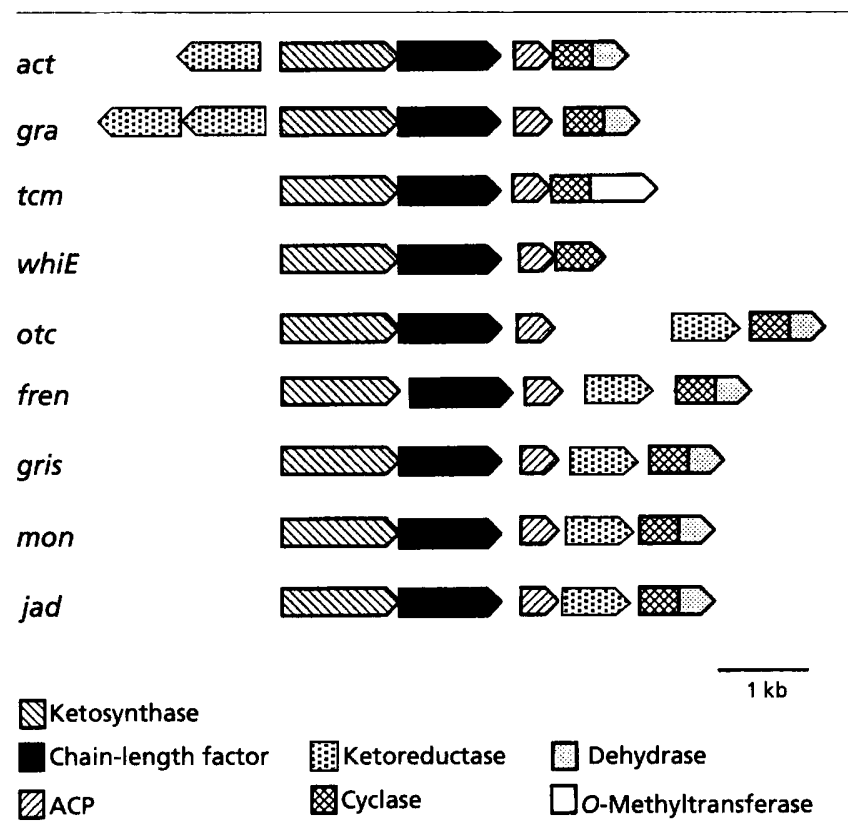

Fig. 6. A diagrammatic comparison of gene organization in the PKS clusters cloned from $S$. coelicolor A3(2) (act and whiE), $S$. violaceoruber (gra), S. glaucescens (tcm), S. rimosus (otc), S. roseoflavus (fren), S. griseus (gris), S. cinnamonensis (mon), and S. venezuelae ISP5230 ( $j a d)$ : see text for references. for their production. Under conditions optimized for jadomycin biosynthesis, strain 13s (UC2374) produces these compounds in yields similar to ISP5230 (Singh, 1992).

The five ORFs located in the $4.8 \mathrm{~kb}$ of $S$. venezuelae ISP5230 DNA sequenced show marked similarity to genes in streptomycete type II PKS clusters. A tentative assignment of their functions based on comparisons of derived amino acid sequences suggests that ORF1 encodes a ketoacyl synthase, ORF2 a closely related polypeptide that influences the chain length of the PKS product, ORF3 an ACP, ORF4 a bifunctional cyclase/dehydrase, and ORF5 a ketoreductase. The presence of ORF5 among the jad (jadomycin biosynthesis) genes is consistent with the absence from the jadomycin B structure of a hydroxyl group at C-10 (see Fig. 1). In containing the ORF5 ketoreductase function, the jad PKS differs from those of tcm (Bibb et al., 1989), whiE (Davis \& Chater, 1990) and sch (S. halstedii spore pigment; Blanco et al., 1993; whereas the $\mathrm{tcm}$ metabolite (tetracenomycin $\mathrm{C}$ ) retains an oxygen substituent at $\mathrm{C}-3$, jadomycin $\mathrm{B}$ at the corresponding position (nine carbons from the carboxyl end of the polyketide chain; Bartel et al., 1990) is unsubstituted. The arrangement of ORFs 1,2 and 3 in the group of jad PKS genes has features in common with most type-II streptomycete PKS genes (Fig. 6), but the location of ORF5 places $j a d$ in the subset represented by otc (Kim et al., 1994), 'fren' (Bibb et al., 1994), gris (Yu et al., 1994) and the mon cluster of $S$. cinnamonensis (Arrowsmith et al., 1992). In these groups, ORF5 is located between ORF3 and ORF4, although with various spacings; the jad arrangement most closely resembles that of gris, the PKS gene cluster for griseusin biosynthesis in Streptomyces griseus. Griseusin (Tsuji et al., 1976) and jadomycin are probably each derived from $\mathrm{C}_{20}$ polyketide intermediates that fold in a similar pattern. The arrangement of the mon gene cluster differs from those of jad and gris only in the closer spacing of ORFs 3 and 5. Although the mon metabolite has not yet been chemically characterized, the polyether antibiotic monensin and spore pigments are excluded as candidates (Arrowsmith et al., 1992) and a structural relationship to jadomycin is possible.

No attempt was made to determine whether the size or DNA structure of the insert accounted for the failure of pJV62, containing the $0.6 \mathrm{~kb} S \mathrm{maI}$ fragment of ORF1, to integrate into the $S$. venezuelae ISP5230 chromosome, whereas integration occurred when the vector carried the $2.6 \mathrm{~kb}$ Pst I fragment containing the C-terminal portion of ORF2, the complete sequence of ORF3 and ORF5, and the N-terminal portion of ORF4. Information on expression of the jad PKS genes is lacking, but the corresponding act PKS genes all lie within a single transcriptional unit (Fernández-Moreno et al., 1992). The isolation of $S$. venezuelae transformants disrupted in jadomycin $\mathrm{B}$ production not only indicates that the PKS gene cluster is involved in jadomycin B biosynthesis, but also supports the assumption that ORFs 2-4 are cotranscribed. Production of a small amount of jadomycin B by the disruptants suggests that during growth of the culture, some of the mycelium had excised pJV63, thereby 
restoring jadomycin B synthesis. Jadomycin production increased as expected when disruptant cultures were supplemented with $50 \mu \mathrm{g}$ thiostrepton $\mathrm{ml}^{-1}$, which would select for strains with high-level thiostrepton resistance resulting from excision of the multi-copy vector. Excision of integrated plasmids is not unexpected (MacNeil et al., 1992).

\section{ACKNOWLEDGEMENTS}

We are grateful to Dr D. A. Hopwood for providing plasmids pI J2345 and pIJ2346, to Dr C. L. Hershberger for pHJL400, and Dr D. J. MacNeil for a culture of E. coli ET12567. We thank Drs J. A. Doull and S. W. Ayer for a sample of jadomycin $\mathrm{B}$, and for valuable discussions. This work was supported by the Natural Sciences and Engineering Research Council of Canada.

\section{REFERENCES}

Ahmed, Z. U. \& Vining, L. C. (1983). Evidence for a chromosomal location of the genes coding for chloramphenicol production in Streptomyces venezuelae. J Bacteriol 154, 239-244.

Aidoo, D. A., Barrett, K. \& Vining, L. C. (1990). Plasmid transformation of Streptomyces venequelae: modified procedures used to introduce the genes for $p$-aminobenzoate synthetase. $J$ Gen Microbiol 136, 657-662.

Arrowsmith, T. J., Malpartida, F., Sherman, D. H., Birch, A., Hopwood, D. A. \& Robinson, J. A. (1992). Characterization of act homologous DNA encoding polyketide synthase genes from the monensin producer Streptomyces cinnamonensis. Mol \& Gen Genet 234, 254-264.

Ayer, S. W., Mclnnes, A. G., Thibault, P., Walter, J. A., Doull, J. L., Parnell, T. \& Vining, L. C. (1991). Jadomycin, a novel $8 \mathrm{H}$ benz[b]oxazolo[3,2-f]phenanthridine antibiotic from Streptomyces venezuelae ISP5230. Tetrabedron Lett 32, 6301-6304.

Bartel, P. L., Zhu, C.-B., Lampel, J. S., Dosch, D. C., Connors, N. C., Strohl, W. R., Beale, J. M., Jr \& Floss, H. G. (1990). Biosynthesis of anthraquinones by interspecies cloning of actinorhodin biosynthetic genes in streptomycetes: clarification of actinorhodin gene functions. $J$ Bacteriol 172, 4816 4826.

Bibb, M. J., Findlay, P. R. \& Johnson, M. W. (1984). The relationship between base composition and codon usage in bacterial genes and its use in the simple and reliable identification of proteincoding sequences. Gene 30, 157-166.

Bibb, M. J., Biró, S., Motamedi, H., Collins, J. F. \& Hutchinson, C. R. (1989). Analysis of the nucleotide sequence of the Streptomyces glaucescens $t \mathrm{cmI}$ genes provides key information about the enzymology of polyketide antibiotic biosynthesis. EMBO $J \mathbf{8}$, 2727-2736.

Bibb, M. J., Sherman, D. H., Ōmura, S. \& Hopwood, D. A. (1994). Cloning, sequencing and deduced functions of a cluster of Streptomyces genes probably encoding biosynthesis of the polyketide antibiotic frenolicin. Gene 142, 31-39.

Blanco, G., Pereda, A., Mendez, C. \& Salas, J. (1992). Cloning and disruption of a fragment of Streptomyces balstedii DNA involved in the biosynthesis of a spore pigment. Gene 112, 59-65.

Blanco, G., Brian, P., Pereda, A., Mendez, C., Salas, J. A. \& Chater, K. F. (1993). Hybridization and DNA sequence analysis suggest an early evolutionary divergence of related biosynthetic gene sets encoding polyketide antibiotics and spore pigments in Streptomyces spp. Gene 130, 107-116.

Carter, P., Bedovelle, H. \& Winter, G. (1985). Improved oligo- nucleotide site-directed mutagenesis using M13 vectors. Nucleic Acids Res 13, 4431-4443.

Davis, N. K. \& Chater, K. F. (1990). Spore colour in Streptomyces coelicolor A3(2) involves the developmentally regulated synthesis of a compound biosynthetically related to polyketide antibiotics. $\mathrm{Mol}$ Microbiol 4, 1679-1691.

Denhardt, D. T. (1966). A membrane filter technique for the detection of complementary DNA. Biochem Biophys Res Commun 23, 641-646.

Doull, J. L., Ahmed, Z., Stuttard, C. \& Vining, L. C. (1985). Isolation and characterization of Streptomyces venequelae mutants blocked in chloramphenicol biosynthesis. J Gen Microbiol 131, 97-104.

Doull, J. L., Ayer, S. W., Singh, A. K. \& Thibault, P. (1993). Production of a novel polyketide antibiotic, jadomycin B, by Streptomyces venezuelae following heat shock. J Antibiot 46, 869-871.

Doull, J. L., Singh, A. K., Hoare, M. \& Ayer, S.W. (1994). Conditions for the production of jadomycin B by Streptomyces venezuelae ISP5230: effects of heat shock, ethanol treatment and phage infection. J Ind Microbiol 13, 120-125.

Fernández-Moreno, M. A., Martínez, E., Boto, L., Hopwood, D. A. \& Malpartida, F. (1992). Nucleotide sequence and deduced functions of a set of co-transcribed genes of Streptomyces coelicolor A3(2) including the polyketide synthase for the antibiotic actinorhodin. J Biol Chem 267, 19278-19290.

Hallam, S. E., Malpartida, F. \& Hopwood, D. A. (1988). Nucleotide sequence, transcription and deduced function of a gene involved in polyketide antibiotic synthesis in Streptomyces coelicolor. Gene 74, 305-320.

Hopwood, D. A. \& Khosla, C. (1992). Genes for polyketide secondary metabolic pathways in microorganisms and plants. CIB $A$ Found Symp 171, 88-112.

Hopwood, D. A. \& Sherman, D. H. (1990). Molecular genetics of polyketides and its comparison to fatty acid biosynthesis. Annu Rev Genet 24, 37-66.

Hopwood, D. A., Bibb, M. J., Chater, K. F., Kieser, T., Bruton, C. J., Kieser, H. M., Lydiate, D. J., Smith, C. P. \& Schrempf, H. (1985). Genetic Manipulation of Streptomyces: a Laboratory Manual. Norwich, UK: John Innes Foundation.

Kieser, T. (1984). Factors affecting the isolation of ccc DNA from Streptomyces lividans and Eschericbia coli. Plasmid 12, 290-296.

Kim, E.-S., Bibb, M. J., Butler, M. J., Hopwood, D. A. \& Sherman, D. H. (1994). Sequences of the oxytetracycline polyketide synthaseencoding otc genes from Streptomyces rimosus. Gene 141, 141-142.

Larson, J. L. \& Hershberger, C. L. (1986). The minimal replicon of a streptomycete plasmid produces an ultrahigh level of plasmid DNA. Plasmid 15, 199-209.

Malpartida, F., Hallam, S. E., Kieser, H. M. \& Hopwood, D. A. (1987a). Organization of the actinorhodin genes of Streptomyces coelicolor and their use as probes to isolate other polyketide biosynthetic genes: implications for 'hybrid' antibiotic production. In Proceedings of the 5th International Symposium Genetics of Industrial Microorganisms, 1986, pp. 29-39. Edited by M. Alačevič, D. Hranueli \& Z. Toman. Zagreb, Yugoslavia: Pliva.

Malpartida, F., Hallam, S. E., Kieser, H. M., Motamedi, H., Hutchinson, C. R., Butler, M. J., Sugden, D. A., Warren, M., McKillop, C., Bailey, C. R., Humphreys, G. O. \& Hopwood, D. A. (1987b). Homology between Streptomyces genes coding for synthesis of different polyketides used to clone antibiotic biosynthetic genes. Nature 325, 818-821.

McDaniel, R., Ebert-Khosla, S., Hopwood, D. A. \& Khosla, C. (1993). Engineered biosynthesis of novel polyketides. Science 262, 1546-1550. 
MacNeil, D. J. (1988). Characterization of a unique methyl-specific restriction system in Streptomyces avermitilis. $J$ Bacteriol 170, 5607-5612.

MacNeil, D. J., Gewain, K. M., Rudy, C. L., Dezeny, G., Gibbons, P. H. \& MacNeil, T. (1992). Analysis of Streptomyces avermitilis genes required for avermectin biosynthesis utilizing a novel integration vector. Gene 111, 61-68.

Meese, E., Olson, S., Leis, L. \& Trent, J. (1990). Quick method for high yields of lambda bacteriophage DNA. Nucleic Acids Res 18, 1923.

O'Hagan, D. (1992). Biosynthesis of polyketide metabolites. Nat Prod Rep 9, 447-479.

Sambrook J., Fritsch, E. F. \& Maniatis, T. (1989). Molecular Cloning, a Laboratory Manual. Cold Spring Harbor, NY: Cold Spring Harbor Laboratory.

Sanger, F., Nicklen, S. \& Coulson, A. R. (1977). DNA sequencing with chain-terminating inhibitors. Proc Natl Acad Sci USA 74, 5463-5467.

Shen, B. \& Hutchinson, C. R. (1993). Enzymatic synthesis of a bacterial polyketide from acetyl and malonyl coenzyme A. Science 262, 1535-1540.

Sherman, D. H., Malpartida, F., Bibb, M. J., Kieser, H. M., Bibb, M. J. \& Hopwood, D. A. (1989). Structure and deduced function of the granaticin producing polyketide synthase gene cluster of Streptomyces violaceoruber TÜ22. EMBO J 8, 2717-2725.

Singh, A. K. (1992). Production of the antibiotic jadomycin $B$ by $S$. venequelae ISP 5230: effects of beat and ethanol. MSc thesis, Dalhousie University, Halifax, Canada.

Southern, E. M. (1975). Detection of specific sequences among DNA fragments separated by gel electrophoresis. J Mol Biol 98, 503-517.

Stuttard, C. (1982). Temperate phages of Streptomyces venezuelae: lysogeny and host specificity shown by phages SV1 and SV2.J Gen Microbiol 128, 115-121.

Tsuji, N., Kobayashi, M., Terui, Y. \& Tori, K. (1976). The structures of griseusins $\mathrm{A}$ and $\mathrm{B}$, new isochromanequinone antibiotics. Tetrabedron 32, 2207-2210.

Vining, L. C. \& Westlake, D. W. S. (1984). Chloramphenicol: properties, biosynthesis and fermentation. In Biotechnology of Industrial Antibiotics, pp. 387-409. Edited by E. J. Vandamme. New York: Marcel Dekker.

Yu, T.-W., Bibb, M. J., Revill, W. P. \& Hopwood, D. A. (1994). Cloning, sequencing and analysis of the griseusin polyketide synthase gene cluster from Streptomyces griseus. J Bacteriol 176, 2627-2634.

Zhang, H. L., He, X. G., Adeferati, A., Gallucci, J., Cole, S. P., Beale, J. M., Keller, P. J., Chang, C. J. \& Floss, H. G. (1990). Mutactin, a novel polyketide from Streptomyces coelicolor: structure and biosynthetic relationship to actinorhodin. $J$ Org Chem 55, 1682-1684.

Received 1 June 1994; revised 25 August 1994; accepted 19 September 1994. 